\title{
Basic Chemistry Practicum Handbook with Occupational Health and Safety (K3) to Prevent Work Accidents in Laboratory: Validity and Feasibility
}

\author{
I Ketut Sudiana ${ }^{1 *}$, I Wayan Suja² ${ }^{2}$ I Dewa Ketut Sastrawidana ${ }^{3}$, I Nyoman Sukarta ${ }^{4}$ iD \\ 1,2,3,4 Ganesha University of Education, Singaraja, Indonesia \\ *Corresponding author: sudi.ana@undiksha.ac.id
}

\begin{abstract}
First year students of the Chemistry Education Study Program have some problems in practicum because the students' basic laboratory skills are low. The current practicum guide is not sufficient to provide information on basic skills for working in the laboratory. This condition causes students to have problems practicum and there is a potential risk of accidents. This study aims to produce a handbook for Basic Chemistry I with Occupational Health and Safety (K3) which is feasible to be implemented in Basic Chemistry Practicum I. This research was a Research and Development (R\&D) with a 4-D development model, consist of 4 main stages, Define, Design, Develop and Disseminate. The research was limited to the development stage, which ended in the legibility test. Based on expert assessment the results showed that the handbook for Basic Chemistry Practicum I with K3 was very valid in terms of content (3.75), language (3.70), and media (3.6) from a maximum score of 4 . The results of the readability test from 9 students showed that all students gave clear assessments. They understood the contents and guidelines for practicum on Basic Chemistry 1 with K3 very well. The conclusion of this study is Basic Chemistry Practicum I Handbook with K3 content is valid to be implemented from the aspects of content, presentation, language, media, and readability.
\end{abstract}

Keywords: Practicum Guide, Basic Chemistry, Occupational Health and Safety

$\begin{array}{lll}\text { History: } & \text { Publisher: Undiksha Press } \\ \text { Received } & : 24 \text { August } 2020 & \text { Licensed: This work is licensed under } \\ \text { Revised } & : 1 \text { September } 2020 & \text { a Creative Commons Attribution } 3.0 \text { License } \\ \text { Accepted } & : 26 \text { September } 2020 & \end{array}$

\section{Introduction}

Chemistry is a branch of science that has characteristics based on experiments. In chemistry learning, understanding concepts and theories need practicum as a direct learning experience. In chemistry there are two things that closely related, chemistry as a product (chemical knowledge in the form of facts, concepts, theories, and principles) and the process (scientific work) (Effendi-Hasibuan, Fuldiaratman, Dewi, Sulistiyo, \& Hindarti, 2020; Hairida, 2018; Maison et al., 2020). Both of these things can be achieved by students through practicum. Practicum guide is needed to make practicum carried out well or following the objectives to be achieved. A practicum guide is a facility provided by lecturers/teachers so that students can learn and work well (Maison et al., 2020; Sumarti, Nuswowati, \& Kurniawati, 2018).

Laboratory as a place for practicum takes high seriousness, although it depends on the guidelines made by teachers or lecturers and students do the work (Hill Jr \& Finster, 2016; WHO, 2011). They must work with the chemicals they use safely. A laboratory is a place for teaching staff (lecturers and teachers), students, and laboratory workers to make experiment with chemicals, glassware, and special tools. The use of these chemicals and tools has work 
accidents potential. Most work accidents are caused by unsafe behavior, the rest by unsafe conditions. The causes of work accidents are due to unsafe behavior (88\%), unsafe conditions (10\%), and unknown (2\%). Another study conducted by Gibson, Schröder, \& Wayne (2014) also shows that work accidents are caused by unsafe behavior $(96 \%)$ and unsafe conditions (4\%). Based on these data, it can be concluded that in general, work accidents are the main cause of carelessness. Therefore it is necessary to make efforts to prevent accidents by developing awareness (attitudes) to the importance of $\mathrm{K} 3$ for those who work in the laboratory.

Occupational Health and Safety (K3) is important to be implemented because it prevents and reduces the risk of work accidents, due to the lack of awareness of laboratory managers on K3 implementation and laboratory infrastructure that does not follow K3 in work accidents (Dwi, 2017; Greenhaus \& Allen, 2011; Styawan, Sukardi, Rahdiyanta, Wijanarka, \& Ngadiyono, 2019). Occupational Health and Safety (K3) requires special attention because $\mathrm{K} 3$ is a form to create a workplace that is safe, healthy, free from environmental pollution, so that it can reduce and or be free from occupational accidents and diseases, which in the end can increase work efficiency and productivity (Abraham et al., 1997; Purnomo \& Saputro, 2018; Taylor, 1995; Yamin, 2020). Work accidents not only cause casualties or material loss, environmental damage, but can also interfere with the process of achieving the objectives of practicum learning in the laboratory. Therefore, K3 should be attached to the practicum.

As previously explained, the main cause of work accidents is unsafe behavior or carelessness. Work accidents in the laboratory can be prevented by changing unsafe behavior into safe behavior for laboratory workers. An alternative effort that can be made is increasing awareness (attitudes) and practices of occupational safety and health in the laboratory through the development of a practicum guide with $\mathrm{K} 3$. The importance of developing a practical guide is to activate students and develop student skills through activities in the practicum guide that has been developed (Prayitno, 2017).

Basic Chemistry is one of the courses in Chemistry Education study program FMIPA Undiksha and its existence is important because it is one of the basic sciences so this course is in the first year. Basic Chemistry is also related to further chemistry courses, such as organic chemistry, inorganic chemistry, physical chemistry, analytical chemistry, and biochemistry. Basic Chemistry is equipped with practicum, therefore a practicum guide is needed in conducting Basic Chemistry courses so that the practicum is carried out well and achieve the objectives. One of them is the Basic Chemistry Practicum Guide I which is the focus of this development research.

In general, a practicum guide contains objectives, short material related to the title to be practiced, the tools and materials used, and practicum procedures. The current Basic Chemistry Practicum I Guide does not include basic skills for working in a laboratory which is outlined in the form of standard operating procedures (SOP) for working in the laboratory, to prevent work accidents in the laboratory. As educational students (prospective teachers), it is important for Chemistry Education Study Program students to master basic laboratory skills and K3 application in the laboratory which is part of the graduate competence standard (SKL) so that they will become professional teachers.

Based on the experience of guiding students to carry out Basic Chemistry Practicum I, there was a lack of students' skills in practicum, including using chemical tools and materials, and following work procedures correctly according to Standard Operating Procedures (SOP). This has the potential to trigger work accidents in the laboratory, thus results in not achieving the objectives of the practicum. Several reports stated that there had been work accidents in the laboratory. According to a survey conducted by the Education Bureau in 2011/2012, it was found that from 401 high schools, there were 348 cases of work 
accidents in the Chemistry laboratory. The Chemistry Laboratory in the school get the second rank as a laboratory that often have work accidents.

Educational laboratories have a higher risk of work accidents than laboratories for industrial activities. This happens because in the educational laboratory the practitioners are still in the learning stage and generally have not mastered work procedures properly. The activities are carried out using different tools and materials for each practicum, while in industrial laboratories the activities carried out by the practitioners are carried out continuously with the same tools and materials every day. This study aims to produce a handbook for Basic Chemistry I with Occupational Health and Safety (K3) which is feasible to be implemented in Basic Chemistry Practicum I. This study was conducted to prevent work accidents in the laboratory.

\section{Materials and Methods}

This research is a development research or Research and Development (R\&D) using a 4-D development model, consist of 4 main stages, Define, Design, Develop, and Disseminate (Thiagarajan, Semmel, \& Semmel., 1974). Borg \& Gall (1983) states that it is possible to limit research on a small scale, limiting the research steps. The impact of Covid-19 pandemic has made Undiksha applies WFH (Work From Home), where all the activities of the learning process and practicum are carried out from home. Related to this, this research can only be carried out in three stages, Define, Design, and Develop. The development stage ends up with the legibility test. Practicality tests and test effectiveness cannot be implemented because there are no practicum activities carried out in the laboratory.

\section{Results and Discussion Results}

Following is the 4-D development procedure used in this development research.

\section{Define Stage}

At the defined stage, a needs analysis was carried out through a preliminary study with interviews, observation, and document study. Based on the preliminary study, it was found that the problem in organizing the Basic Chemistry I was the low skills of students in practicum which caused the practicum did not run smoothly, the objectives of the practicum were not achieved optimally, and had the potential to cause work accidents in the laboratory. The low skills of first-year students (new students) in practicum were due to their inexperience during high school. The practicum guide used was the Basic Chemistry Practicum I guide was compiled by Subagia \& Sya'ban (2004). This handbook has not provided sufficient information regarding work safety and security in the laboratory.

\section{Design Stage}

Based on the results obtained in the define stage, then the initial design stage was carried out. The initial design meant at this stage was the design of the Basic Chemistry Practicum Handbook I with K3 which was developed before being tested on students. This stage was media selection and format selection. The media used is an image used to clarify practical instructions or working procedures in the laboratory, so that students can carry out practicum correctly and safely. At this design stage, a practical handbook format was also chosen. The format is the one that meets the criteria of being attractive, easy, and helpful in learning. The format or systematics of the Basic Chemistry Practicum Handbook I with K3 is presented in Table 1. 
Table 1. Systematics of the Basic Chemistry Practicum Handbook

\begin{tabular}{ll}
\hline & Practicum Handbook Systematics \\
\hline Introduction & 1. Title \\
& 2. Preface \\
& 3. Instructions \\
& 4. Table of Contents \\
& 5. List of Attachments \\
& 6. Rules of Basic Chemistry Practicum I \\
& 7. Basic Laboratory Knowledge \\
& 8. Basic Techniques for Laboratory Skills \\
Contents (Contains Six Experiment & I. Title \\
Topics) & II. Purpose \\
& III. Basic theory \\
& IV. Tools and Materials \\
& V. Work Procedures \\
& VI. Observation Sheet \\
& VII. Data analysis \\
& VIII. Discussion \\
& IX. Question \\
& X. Conclusion \\
XI. References \\
XII. Practicum Ratification Identity Sheet \\
References \\
K3 attachment in SOP form \\
The Example of Report \\
\hline
\end{tabular}

Develop Stage

The development stage was divided into two activities: expert appraisal and developmental testing. Expert appraisal is a technique for validating or assessing the feasibility of a product design. The assessment includes aspects: content, language, and media. A summary of the results of validation by experts is presented in Table 2 .

Table 2 shows that the expert judged very feasible/very valid in all aspects of the assessed product development. Some suggestions for improvement from experts included fixing typing errors (typos), improving the consistency of the presentation format and image layout, and improving image quality. After revisions were made based on the advice of the experts and after the product was declared feasible by the expert, a development test was carried out in the form of a legibility test. The legibility test involved 9 students. The legibility test results are presented in Table 3.

Based on Table 3, it shows that all students assessment gives clear or understood until it was very clear or very understood about the Basic Chemistry Practicum I with K3 contents and procedures.

Table 2. Summary of Expert Validation Results

\begin{tabular}{cccc}
\hline \multirow{2}{*}{ Rated Aspect } & \multicolumn{2}{c}{ Judges } & \\
\cline { 2 - 3 } & First & $\begin{array}{c}\text { Second } \\
\text { Average }\end{array}$ Category \\
& Expert & Expert
\end{tabular}

Content Validity

A Content eligibility

1 The contents appropriate with KD

4.00

Very Valid 


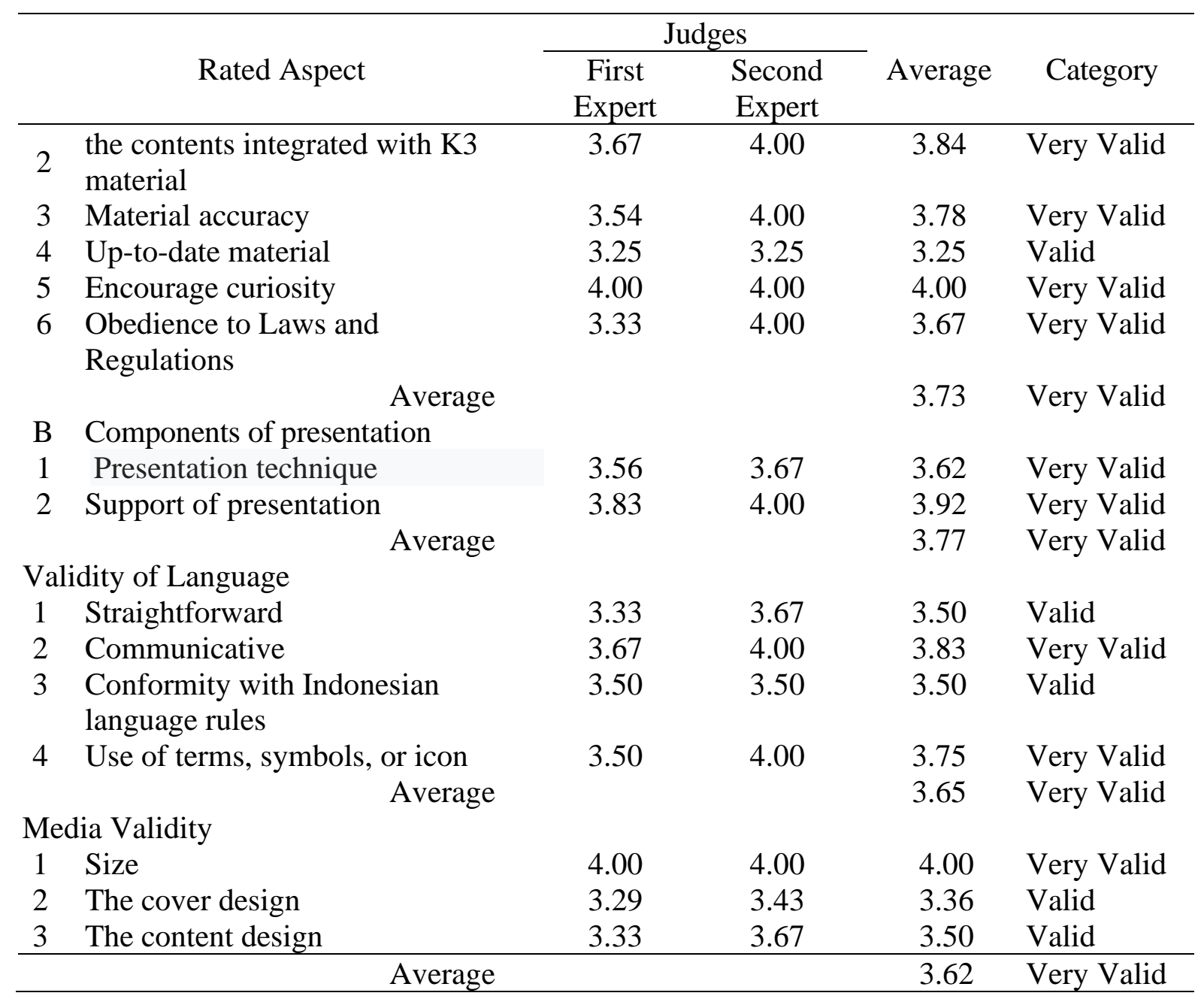

Table 3. Summary of Readability Test Results

\begin{tabular}{|c|c|c|c|c|c|c|c|c|c|}
\hline \multirow[t]{2}{*}{ No. } & \multirow[t]{2}{*}{ Rated Aspect } & \multicolumn{2}{|c|}{$\begin{array}{l}\text { Not } \\
\text { Clear }\end{array}$} & \multicolumn{2}{|c|}{ Unclear } & \multicolumn{2}{|c|}{ Clear } & \multicolumn{2}{|c|}{ Very Clear } \\
\hline & & $\mathrm{n}$ & $\%$ & $\mathrm{n}$ & $\%$ & $\mathrm{n}$ & $\%$ & $\mathrm{n}$ & $\%$ \\
\hline 1 & $\begin{array}{l}\text { The sentence used represents the } \\
\text { information to be conveyed }\end{array}$ & 0 & 0 & 0 & 0 & 5 & 55.56 & 4 & 44.44 \\
\hline 2 & $\begin{array}{l}\text { The use of language does not } \\
\text { create a double meaning }\end{array}$ & 0 & 0 & 0 & 0 & 6 & 66.67 & 3 & 33.33 \\
\hline 3 & $\begin{array}{l}\text { The words used are understood } \\
\text { (familiar or familiar) }\end{array}$ & 0 & 0 & 0 & 0 & 7 & 77.78 & 2 & 22.22 \\
\hline 4 & $\begin{array}{l}\text { The practicum procedure } \\
\text { presented is easy to understand }\end{array}$ & 0 & 0 & 0 & 0 & 1 & 11.11 & 8 & 88.89 \\
\hline 5 & $\begin{array}{l}\text { The images / tables / charts that } \\
\text { are presented are informative and } \\
\text { make it easier to understand work } \\
\text { procedures }\end{array}$ & 0 & 0 & 0 & 0 & 1 & 11.11 & 8 & 88.89 \\
\hline 6 & $\begin{array}{l}\text { Clarity of writing chemical } \\
\text { formulas and symbols / symbols }\end{array}$ & 0 & 0 & 0 & 0 & 3 & 33.33 & 6 & 66.67 \\
\hline 7 & $\begin{array}{l}\text { Systematic clarity of content / } \\
\text { practical guidance material }\end{array}$ & 0 & 0 & 0 & 0 & 4 & 44.44 & 5 & 55.56 \\
\hline 8 & SOP (Standard Operating & 0 & 0 & 0 & 0 & 2 & 22.22 & 7 & 77.78 \\
\hline
\end{tabular}




\begin{tabular}{|c|c|c|c|c|c|c|c|c|c|}
\hline \multirow[t]{2}{*}{ No. } & \multirow[t]{2}{*}{ Rated Aspect } & \multicolumn{2}{|c|}{$\begin{array}{l}\text { Not } \\
\text { Clear }\end{array}$} & \multicolumn{2}{|c|}{ Unclear } & \multicolumn{2}{|c|}{ Clear } & \multicolumn{2}{|c|}{ Very Clear } \\
\hline & & $\mathrm{n}$ & $\%$ & $\mathrm{n}$ & $\%$ & $\mathrm{n}$ & $\%$ & $\mathrm{n}$ & $\%$ \\
\hline & $\begin{array}{l}\text { Procedure) clarifies the } \\
\text { understanding of practicum work } \\
\text { procedures }\end{array}$ & & & & & & & & \\
\hline 9 & $\begin{array}{l}\text { SOPs and K3 (Work safety and } \\
\text { security) information help } \\
\text { understand working in a safe and } \\
\text { secure laboratory }\end{array}$ & 0 & 0 & 0 & 0 & 1 & 11.11 & 8 & 88.89 \\
\hline 10 & $\begin{array}{l}\text { A practicum guide equipped with } \\
\text { SOP and K } 3 \text { information makes } \\
\text { you feel confident and doesn't } \\
\text { hesitate to work in the laboratory }\end{array}$ & 0 & 0 & 0 & 0 & 1 & 11.11 & 8 & 88.89 \\
\hline
\end{tabular}

\section{Discussion}

The results of the analysis of the Basic Chemistry Practicum I Syllabus of the Chemistry Education Study Program (Silabus Program Studi Pendidikan Kimia Kurikulum 2019) obtained minimum competencies that students must achieve. Students can design, conduct, and report practicum results by utilizing the potentially available resources to build science process skills and chemical concepts about the material and its changes; atomic structure and periodic system; chemical bonds, molecular and crystal structures; concepts in stoichiometry; and chemical energy. Furthermore, based on the minimum competency formulation, there were 6 topics of Basic Chemistry I practicum, namely Separation and Purification of Substances, Chemical Reactions, Determination of Relative Atomic Mass of $\mathrm{Mg}$, Determination of the Formula of a Hydrate, Continuous Variation and Stoichiometry, and Determination of the Relative Molecular Mass of Oxygen. These six topics were further developed with K3 content. From 6 practicum topics successfully identified the risk of accidents and the concept of $\mathrm{K} 3$ action that must be mastered by students. The risks of accidents include damages to glass, metal and porcelain tools, inhalation of the reaction gases, direct contact with chemicals through the skin, eyes, mouth and respiratory tract, gas leaks, and fire hazard (Abbas, Zakaria, Balkhyour, \& Kashif, 2016; Harrison, Heslop, Eastman, Baldwin, \& Shallcross, 2011; WHO, 2011).

The concepts of K3 actions important for students to master to prevent work accidents are training on the use of practical tools, using Personal Protective Equipment (PPE), gasproducing reactions carried out in a fume hood, and training on the use of a Light Fire Extinguisher (APAR). The K3 concept or action includes 26 work procedures which were then formulated or compiled into 26 SOPs (Standard Operational Procedures), namely SOP for Work Safety, SOP for Washing Volumetric Equipment (Burette, Pipette, and Measuring Flask), SOP for Titration, SOP for Vacuum Filtering, SOP for Gravity Screening, SOP for Decantation, SOP for Moving Liquids with Dropper Pipettes, SOP for Sipping and Transferring Liquids with Volumetric Pipettes and Measuring Pipettes, SOP for Moving Liquids, SOP for Transferring Solids, SOP for Heating Liquids, SOP for Weighing Substances Using a Digital Analytical Balance, SOP for Weighing Substances Using an Analog Analytical Balance (3-Arm Ohaus Balance), SOP for Making Solutions with Certain Concentrations of Pure Solids, SOP for Making Specific Concentration Solutions by Dilution, SOP for Disposing / Handling Waste, SOP for Smelling the Odor of Reaction Gases, SOP for Testing Acidity / Solubility of Solutions, SOP for Taking Solids from Pure Stock, SOP for Taking Liquid Substances from Pure Stock, SOP for Drying Solids, SOP Using a Fume Hood, SOP Using Statives and Clamps, SOP Using a Thermometer, SOP for Steaming 
Liquids, and SOP for Using a Light Fire Extinguisher (APAR). The concept of K3 in the form of SOP is integrated into the practicum guide using the insertion method (Purnomo \& Saputro, 2018; Taylor, 1995; Yamin, 2020). The preparation of the SOP follows the criteria as set out in the SOP preparation references (Setyawan et al., 2019; Tathagati, 2014) to the importance of $\mathrm{K} 3$ for those who work in the laboratory.

Occupational Health and Safety (K3) is important to be implemented because it prevents and reduces the risk of work accidents, due to the lack of awareness of laboratory managers on K3 implementation and laboratory infrastructure that does not follow K3 in work accidents (Dwi, 2017; Greenhaus \& Allen, 2011; Styawan, Sukardi, Rahdiyanta, Wijanarka, \& Ngadiyono, 2019). Occupational Health and Safety (K3) requires special attention because $\mathrm{K} 3$ is a form to create a workplace that is safe, healthy, free from environmental pollution, so that it can reduce and or be free from occupational accidents and diseases, which in the end can increase work efficiency and productivity (Abraham et al., 1997; Purnomo \& Saputro, 2018; Taylor, 1995; Yamin, 2020). Work accidents do not only cause casualties or material loss and environmental damage, but can also interfere with the process of achieving the objectives of practicum learning in the laboratory. Therefore, K3 should be attached to the practicum.

Basic Chemistry is one of the courses in the Chemistry Education study program FMIPA Undiksha and its existence is important because it is one of the basic sciences so this course is in the first year. Basic Chemistry is also related to further chemistry courses, such as organic chemistry, inorganic chemistry, physical chemistry, analytical chemistry, and biochemistry. Basic Chemistry is equipped with practicum, therefore a practicum guide is needed in conducting Basic Chemistry courses so that the practicum is carried out well and achieve the objectives. One of them is the Basic Chemistry Practicum Guide I which is the focus of this development research.

In general, a practicum guide contains objectives, short material related to the title to be practiced, the tools and materials used, and practicum procedures. The current Basic Chemistry Practicum I Guide does not include basic skills for working in a laboratory which is outlined in the form of standard operating procedures (SOP) for working in the laboratory to prevent work accidents in the laboratory. As educational students (prospective teachers), it is important for Chemistry Education Study Program students to master basic laboratory skills and K3 application in the laboratory which is part of the Graduate competence standard (SKL) so that they will become professional teachers.

\section{Conclusion}

Based on the results of this development research, it can be concluded that the developed product in the form of a Basic Chemistry Practicum Handbook I with K3 is suitable for use in terms of content, presentation, language, media, and readability aspects. Following the development procedure, ideally, this research should be continued with developmental testing, namely practicality testing and effectiveness testing. The last two tests could not be carried out because practicum activities in the laboratory did not take place due to WFH policies as a result of Covid-19 pandemic.

\section{Acknowledgment}

The authors would like to thank the Universitas Pendidikan Ganesha for providing research funding through DIPA BLU 2020 funds.

\section{References}

Abbas, M., Zakaria, A., Balkhyour, M. M., \& Kashif, M. (2016). Chemical safety in 
academic laboratories: an exploratory factor analysis of safe work practices \& facilities in a university. Journal of Safety Studies, 2(1), 1-14. Retrieved from https://www.academia.edu/download/50052321/8962-34606-1-PB.pdf.

Abraham, M. R., Craolice, M. S., Graves, A. P., Aldhamash, A. H., Kihega, J. G., Gal, J. G. P., \& Varghese, V. (1997). The nature and state of general chemistry laboratory courses offered by colleges and universities in the United States. Journal of Chemical Education, 74(5), 591. https://doi.org/10.1021/ed074p591.

Borg, W. R., \& Gall, M. D. (1983). Educational Research: an Introduction. Longman.

Dwi, A. S. (2017). Studi Tingkat Kecelakaan Lalu Lintas Jalan di Indonesia Berdasarkan Data KNKT ( Komite Nasional Keselamatan Transportasi ) Dari Tahun 2007-2016 Nasional Keselamatan Transportasi ) Database from 2007-2016. Warta Penelitian Perhubungan, 29(2), 179-190.

Effendi-Hasibuan, M. H., Fuldiaratman, Dewi, F., Sulistiyo, U., \& Hindarti, S. (2020). Jigsaw learning strategy in a diverse science-classroom setting: Feasibility, challenges, and adjustment. Cakrawala Pendidikan, 39(3), 733-745. https://doi.org/10.21831/cp.v39i3.30634.

Gibson, J. H., Schröder, I., \& Wayne, N. L. (2014). A research university's rapid response to a fatal chemistry accident: Safety changes and outcomes. Journal of Chemical Health \& Safety, 21(4), 18-26. https://doi.org/10.1021/acs.chas.8b21406.

Greenhaus, J. H., \& Allen, T. D. (2011). Work-family balance: A review and extension of the literature. Handbook of Occupational Health Psychology (2nd ed.). Washington DC: American Psychological Association.

Hairida, H. (2018). Penilaian Sikap Siswa Dalam Pembelajaran Kimia Melalui Teknik Self Assessment Dan Peer Assessment. Jurnal Pendidikan Matematika Dan IPA, 9(2), 3748. https://doi.org/10.26418/jpmipa.v9i2.25832.

Harrison, T. G., Heslop, W. J., Eastman, J. R., Baldwin, A., \& Shallcross, D. E. (2011). Chemistry LabSkills: Software to Support Laboratory Skills from Schools' PreUniversity to University Foundation Courses. Australian Journal Education Chemistry, $71 . \quad$ Retrieved from http://www.chemistry.bristol.ac.uk/bristolchemlabs/Publications/AusJEC_2011(71)_ Harrison.pdf.

Hill Jr, R. H., \& Finster, D. C. (2016). Laboratory safety for chemistry students. John Wiley \& Sons, Inc.

Maison, Darmaji, Aatalini, Kurniawan, D. A., Haryanto, Kurniawan, W., ... Dewi, U. P. (2020). Science process skill in science program higher education. Universal Journal of Educational Research, 8(2), 652-661. https://doi.org/10.13189/ujer.2020.080238.

Prayitno, T. A. (2017). Pengembangan Petunjuk Praktikum Mikrobiologi Program Studi Pendidikan Biologi. Jurnal Biota, 3(1), 31-37. Retrieved from https://core.ac.uk/download/pdf/187090960.pdf.

Purnomo, E. S., \& Saputro, D. E. (2018). Evaluasi Penerapan Prinsip Kesehatan dan Keselamatan Kerja (K3) pada Pelaksanaan Kegiatan Praktikum Mikroteknik di Laboratorium Biologi Fakultas Sains dan Teknologi UIN Sunan Kalijaga. Integrated Lab Journal, 4(2), 207-216. Retrieved from http://202.0.92.5/pusat/integratedlab/article/view/1135.

Styawan, B., Sukardi, T., Rahdiyanta, D., Wijanarka, B. S., \& Ngadiyono, Y. (2019). A comparative study of the occupational health and safety implementation in the industries and vocational high schools in Yogyakarta. IOP Conference Series: Materials Science and Engineering Volume 535. IOP Publishing. Retrieved from https://iopscience.iop.org/article/10.1088/1757-899X/535/1/012028/meta.

Subagia, I. ., \& Sya'ban, S. (2004). Penuntun Praktikum Kimia Dasar I (KIM 4101). IKIP 
Negeri Singaraja.

Sumarti, S. S., Nuswowati, M., \& Kurniawati, E. (2018). Meningkatkan Keterampilan Proses Sains Melalui Pembelajaran Koloid Dengan Lembar Kerja Praktikum Berorientasi Chemo-Entrepreneurship. Phenomenon: Jurnal Pendidikan MIPA, 8(2), 175-184. https://doi.org/10.21580/phen.2018.8.2.2499.

Tathagati, A. (2014). Step by Step Membuat SOP. Efata Publishing.

Taylor, G. (1995). Degree level education in occupational health and safety in Australia. Journal of Occupational Health and Safety, Australia and New Zealand, 11(4), 359371. Retrieved from https://search.informit.org/doi/pdf/10.3316/ielapa.960201377.

Thiagarajan, S., Semmel, D. S., \& Semmel., M. I. (1974). Instructional Development for Training Teachers of Exceptional Children. Indiana University.

WHO. (2011). Laboratory Quality Management System: Handbook. WHO Lyon Office.

Yamin, M. (2020). Perilaku Keselamatan dan Kesehatan Kerja (K3) Siswa dalam Pembelajaran Praktikum di SMKN 2 Sidenreng. Jurnal of Admiration, 1(3), 207-214. Retrieved from http://jurnalsyntaxadmiration.com/index.php/jurnal/article/view/59. 